DOI: $10.19195 / 0137-1134.115 .8$

\author{
MICHAŁ OCHWAT \\ ORCID: 0000-0002-8907-529X \\ Uniwersytet Śląski w Katowicach
}

\title{
PRAWNE FORMY DZIAŁANIA KOMITETU STABILNOŚCI FINANSOWEJ
}

\begin{abstract}
Abstrakt: Podstawowym założeniem niniejszego opracowania jest próba uchwycenia charakteru przyznanych przez ustawodawcę prawnych form działania administracji, stosowanych przez Komitet Stabilności Finansowej (KSF) w świetle dorobku prawa administracyjnego. Specyfika kształtowania polityki i nadzoru makroostrożnościowego w Polsce i w porównywanych systemach prawnych opiera się przede wszystkim na stosowaniu form o charakterze niewładczym, dlatego też zasadne jest zbadanie, na czym opiera się skuteczność mechanizmu oddziaływania na instytucje rynku finansowego oraz czy w tym kontekście możliwe jest urzeczywistnienie celu stabilności finansowej.
\end{abstract}

Słowa kluczowe: rynek finansowy, nadzór, polityka makroostrożnościowa, prawne formy działania

\section{ZAGADNIENIA WPROWADZAJĄCE}

Wdrożenie ram instytucjonalnych polityki makroostrożnościowej w Polsce poprzez powołanie Komitetu Stabilności Finansowej (KSF) w pewien sposób redefiniuje ukształtowane w nauce administracji reguły dotyczące mechanizmów interwencji państwa za pośrednictwem organów administracji oraz zestawu instrumentów potrzebnych do kształtowania zachowań podmiotów gospodarczych. Cele i zadania stawiane przed nadzorem makroostrożnościowym sugerują, że mamy do czynienia z zupełnie nowym wymiarem realizacji polityki gospodarczej państwa, dlatego podstawowym założeniem niniejszego opracowania jest próba uchwycenia charakteru prawnego form działania w zderzeniu z dogmatyką prawa administracyjnego. W szczególności zasadne jest zbadanie, czy wobec braku kompetencji KSF do stosowania form o charakterze władczym możliwe jest urzeczywistnienie celu stabilności finansowej.

Nadzór ostrożnościowy ogólnie polega na czuwaniu nad stabilnością finansową i co do zasady działania podejmowane w tym zakresie będą mieć charakter prewencyjny. Jego istotą jest zapobieganie takiemu stanowi faktycz- 
nemu (sytuacji finansowej), który zagrażałby bezpieczeństwu środków finansowych powierzonych danej instytucji, lub w szerszym wymiarze - zagrażałby stabilności rynku finansowego. Obecnie rozróżnia się sferę analizy i regulacji makroostrożnościowej, obejmującą działania mające na celu monitorowanie ekspozycji na ryzyko systemowe i identyfikowanie potencjalnych zagrożeń stabilności wynikających z sytuacji makroekonomicznej lub rynku finansowego, a także infrastruktury rynku, jak również nadzór mikroostrożnościowy, odnoszący się do wszelkich kwestii związanych z nadzorowaniem bezpieczeństwa i stabilności, realizowany na poziomie poszczególnych instytucji finansowych ${ }^{1}$. Oznacza to, że nadzór makroostrożnościowy dotyczy całego systemu, w odróżnieniu od bezpieczeństwa i stabilności poszczególnych instytucji. Bezpośrednim c elem makroostrożnościowego podejścia do regulacji i nadzoru jest ograniczanie ryzyka wystąpienia zdarzeń niebezpiecznych dla całego systemu finansowego, natomiast ostatecznym celem — unikanie kosztów, jakie mogą być generowane w gospodarce realnej (na przykład utrata produkcji). W ogólnym ujęciu nadzór ostrożnościowy (makro i mikro) realizowany jest w związku z podejściem top-down, zakładającym wypracowanie pożądanego standardu bezpieczeństwa dla systemu jako całości, a następnie przenoszenie go na poszczególne instytucje ${ }^{2}$. W warstwie instytucjonalnej sprawna realizacja celów nadzoru ostrożnościowego wymaga uzyskania spójności i komplementarności perspektywy zarówno makroostrożnościowej, za którą w Polsce odpowiedzialny jest Komitet Stabilności Finansowej (dalej również: KSF, Komitet), jak i mikroostrożnościowej będącej w gestii Komisji Nadzoru Finansowego (dalej: KNF).

Pojawienie się nowych struktur nadzoru makroostrożnościowego na poziomie UE oraz we wszystkich państwach członkowskich należy powiązać z procesem działań sanacyjnych wdrożonych po kryzysie finansowym subprime w 2008 roku. Bezpośredni wpływ na kształt poszczególnych rozwiązań organizacyjnych miały Rekomendacja ESRB/2011/3³ Europejskiej Rady ds. Ryzyka Systemowego ${ }^{4}$ oraz

1 Por. ECB, The role of central banks in prudential supervision, 30 March 2001, s. 3, http:// www.ecb.int/pub/pdf/other/prudentialsupcbrole_en.pdf (dostęp: 3.08.2018).

2 Tak C. Borio, Implementing a macroprudential framework: Blending boldness and realism, BIS, 22 July 2010, s. 2, http://www.bis.org/repofficepubl/hkimr201007.12c.pdf(dostęp: 28.07.2018).

3 Zalecenie Europejskiej Rady ds. Ryzyka Systemowego z dnia 22 grudnia 2011 roku w sprawie mandatu makroostrożnościowego organów krajowych (ERRS/2011/3), (Dz. Urz. UE C 41 z 14.02.2012, s. 1).

${ }^{4}$ Niezależny organ Unii Europejskiej sprawujący nadzór makroostrożnościowy nad europejskim systemem finansowym, działający przy Europejskim Banku Centralnym (EBC). Przewodniczącym Rady Generalnej — organu decyzyjnego ERRS — jest Prezes EBC, a w jej skład wchodzą również prezesi wszystkich banków centralnych krajów członkowskich UE. Zob. Europejska Rada ds. Ryzyka Systemowego (ESRB), http://www.nbp.pl/home.aspx?f=/systemfinansowy/esrb.html (dostęp: 28.07.2018). 
realizacja obowiązków i instrumentów wynikających z regulacji CRD IV ${ }^{5}$ i CRR ${ }^{6}$, wprowadzających instrumenty ostrożnościowe ${ }^{7}$. Podstawowy obowiązek państw członkowskich w tej kwestii polegał na oficjalnym wskazaniu właściwego organu (national competent authority - CA) odpowiedzialnego za nadzór i politykę w omawianym zakresie. Ponadto kraje członkowskie, w myśl art. 136 ust. 1 CRD IV, zostały zobowiązane do wskazania podmiotów mających status organu wyznaczonego (designated authority - DA), którym przyznano kompetencje w zakresie ustalanie wskaźnika bufora antycyklicznego $(C C y B)$, przy czym w niektórych rozwiązaniach instytucjonalnych statusy te $(C A$ i $D A)$ może łącznie mieć jeden organ lub niezależne organy czy podmioty publiczne.

Zgodnie z krajową ustawą o nadzorze makroostrożnościowym nad systemem finansowym i zarządzaniu kryzysowym w systemie finansowym ${ }^{8}$ Komitet Stabilności Finansowej ma status organu właściwego (CA) „w zakresie nadzoru makroostrożnościowego i zarządzania kryzysowego" (art. 3 ust. 1 u.n.m.) oraz organu wyznaczonego (DA) (art. 3 ust. 2 u.n.m.). W tym ostatnim przypadku ów status jest ograniczony do procesu analizy i określania zmian w natężeniu ryzyka makroostrożnościowego lub systemowego w systemie finansowym (art. 458 ust. 1 CRR), natomiast stosowanie dodatkowych, przeciwdziałających temu ryzyku, tak zwanych środków krajowych, które zaostrzają ogólne wymogi ostrożnościowe powierzono ministrowi finansów (art. 458 ust. 2 lit. d, ust. 5 i 10 CRR). Podział jest konsekwencją skupienia wokół ministra finansów ogólnej funkcji regulacji całego rynku finansowego, w tym określania parametrów ostrożnościowych na podstawie CRR, o czym będzie jeszcze mowa.

Skład Komitetu Stabilności Finansowej został tak ukształtowany, aby reprezentować instytucje kluczowe dla kształtowania stabilności finansowej, określane zbiorczo w literaturze finansów mianem, ,instytucji sieci bezpieczeństwa finanso-

5 Dyrektywa Parlamentu Europejskiego i Rady nr 2013/36/UE z dnia 26 czerwca 2013 roku w sprawie warunków dopuszczenia instytucji kredytowych do działalności oraz nadzoru ostrożnościowego nad instytucjami kredytowymi i firmami inwestycyjnymi, zmieniająca dyrektywę 2002/87/ WE i uchylająca dyrektywy 2006/48/WE oraz 2006/49/WE (Dz. Urz. UE L 176 z 27.06.2013, s. 338 ze zm.), dalej: CRD IV.

6 Rozporządzenie Parlamentu Europejskiego i Rady (UE) nr 575/2013 z dnia 26 czerwca 2013 roku w sprawie wymogów ostrożnościowych dla instytucji kredytowych i firm inwestycyjnych, zmieniające rozporządzenie (UE) nr 648/2012 (Dz. Urz. UE L 176 z 27.06.2013, s. 1 ze zm.), dalej: CRR.

7 Szerzej na temat dostępnych instrumentów makroostrożnościowych i ich stosowania: M. Brzozowski, CRD IV, CRR - instrumenty makroostrożnościowe, Warszawa 2014, https://www. nbp.pl/systemfinansowy/crdiv-crr.pdf(dostęp: 22.07.2018); D.K. Rosati, Regulacje makroostrożnościowe a stabilność sektora bankowego, „Bank i Kredyt” 45, 2014, nr 4, s. 388-396; A. Dobrzańska, Makroostrożnościowy wymiar regulacji CRDIV/CRR, „Bezpieczny Bank” 2015, nr 1 (58), s. 7-45.

8 Ustawa z dnia 5 lipca 2015 roku o nadzorze makroostrożnościowym nad systemem finansowym i zarządzaniu kryzysowym w systemie finansowym Dz. Urz. z 2015 r. poz. 1513 ze zm.), dalej: u.n.m.

Przegląd Prawa i Administracji 115, 2018

(C) for this edition by CNS 
wego (safety net)" ". W myśl art. 7 ust. 1 u.n.m. członkami Komitetu są: minister finansów (minister do spraw instytucji finansowych), prezes Narodowego Banku Polskiego, przewodniczący Komisji Nadzoru Finansowego oraz prezes Zarządu Bankowego Funduszu Gwarancyjnego.

\section{OGÓLNA CHARAKTERYSTYKA PRAWNYCH FORM STOSOWANYCH W NADZORZE MAKROOSTROŻNOŚCIOWYM}

Kluczową kwestią w procesie analizy i budzącą jednocześnie największe wątpliwości jest wskazywana w literaturze przesłanka stosowania władczych form działania jako cecha właściwa działania administracji publicznej w kontekście przewidzianych ustawowo kompetencji Komitetu Stabilności Finansowej. Praw ną formą działania administracji jest, ,wyodrębniony lub dający się wyodrębnić, prawem określony, o utrwalonych cechach typ czynności konwencjonalnej lub faktycznej, bądź zespół takich czynności określonego, powołanego do wykonywania zadań z zakresu administracji publicznej podmiotu (bądź zespołów podmiotów) w celu wypełnienia zadań z zakresu administracji publicznej"10. W tym kontekście już we wstępnie należy podkreślić, że głównym przedmiotem analizy będą prawne formy działania w systemie nadzoru makroostrożnościowego wskazane w u.n.m., które stosowane są stricte przez Komitet.

Odnosząc się do ustaleń doktryny prawa administracyjnego, należy podkreślić, że do podstawowych, jednostronnych form prawnych działania organów administracji należą: generalne i abstrakcyjne akty normatywne oraz indywidu-

9 Por. J. Osiński, Stabilność finansowa w Polsce - aspekty systemowe, „Bank i Kredyt” 36, 2005, nr 11-12, dodatek, s. 5; L. Pawłowicz, Sieć bezpieczeństwa finansowego w Unii Europejskiej a Strategia Lizbońska, [w:] Strategia Lizbońska a zarzadzanie wartościa, red. L. Pawłowicz, Warszawa 2006, s. 214-225; A. Jurkowska-Zeidler, Bezpieczeństwo rynku finansowego w świetle prawa Unii Europejskiej, Warszawa 2008, s. 193-206; P. Zapadka, Sieć bezpieczeństwa finansowego (safety net) jako element konstytucji gospodarczej Unii Europejskiej, [w:] Konstytucja gospodarcza Unii Europejskiej. Aksjologia, red. A. Nowak-Far, Warszawa 2010, s. 154; M. Iwanicz-Drozdowska, Sieć bezpieczeństwa finansowego a działalność konglomeratów finansowych, [w:] Konglomeraty finansowe, red. M. Iwanicz-Drozdowska, Warszawa 2007, s. 89-107; A. Ostalecka, Sieć bezpieczeństwa finansowego w obliczu rosnacego zagrożenia utraty stabilności systemów finansowych, [w:] Rynek finansowy. Inspiracje z integracji europejskiej, red. P. Karpuś, J. Węcławski, Lublin 2008, s. 28-34; M. Capiga, W. Gradoń, G. Szustak, Sieć bezpieczeństwa finansowego, Warszawa 2010.

10 Tak K.M. Ziemski, Indywidualny akt administracyjny jako forma prawna działania administracji, Poznań 2005, s. 138.

Przegląd Prawa i Administracji 115, 2018

(C) for this edition by CNS 
alne i konkretne akty administracyjne ${ }^{11}$ mające „charakter władczy” ${ }^{12}$, co należy rozumieć jako ,potencjalną możliwość stosowania ” środków przymusu administracyjnego celem zabezpieczenia realizacji zakazów czy nakazów ustanowionych przez administrację w określonej formie, formie, które to kryterium proponuje się w doktrynie traktować jako „pomocnicze"13.

Charakterystyczne dla przedmiotowego obszaru nadzoru makroostrożnościowego jest to, że funkcjonuje w nim wiele szczególnych form działania o charakterze niewładczym, niedających się zakwalifikować do przedstawionego podzia$\mathfrak{u u}^{14}$. Już na tym etapie należy uściślić, że wśród przewidzianych prawem form działania samego Komitetu ustawodawca nie dopuścił jakichkolwiek form, które spełniałyby kryteria pozwalające zakwalifikować je jako władcze. W szczególności KSF nie ma bezpośrednich kompetencji do wydawania aktów normatywnych czy indywidualnych decyzji administracyjnych skierowanych do instytucji rynku finansowego.

Wśród form prawnych stosowanych stricte przez Komitet Stabilności Finansowej kluczowe znaczenie w procesie kształtowania polityki makroostrożnościowej mają przewidziane ustawowo kompetencje do wydawania: stanowisk, rekomendacji oraz opinii. Przyjmowane są one w drodze uchwały Komitetu, przy czym w odróżnieniu od jego działalności w zakresie zarządzania kryzysowego, w ktorym uchwały zapadają jednomyślnie w obecności wszystkich członków, uchwały w zakresie nadzoru makroostrożnościowego podejmowane są w głosowaniu jawnym, większością głosów, w obecności co najmniej trzech jego członków, w tym przewodniczącego, co jest podyktowane tym, że mogą one być zaadresowane również do tak zwanych właściwych podmiotów, czyli instytucji zaangażowanych w składzie Komitetu (art. 12 ust. 1-3 i 5 u.n.m.). Uchwały KSF w przedmiocie zastosowania stanowisk i rekomendacji mogą być podane do

11 Przykładowo J. Borkowski, Decyzja administracyjna, Łódź-Zielona Góra 1998, s. 23; M. Wierzbowski, A. Wiktorowska, Prawne formy działania administracji, [w:] Prawo administracyjne, red. M. Wierzbowski, Warszawa 2011, s. 188; K.M. Ziemski, op. cit., s. 144; idem, Formy prawne w sferze działań zewnętrznych administracji publicznej, [w:] System Prawa Administracyjnego, t. 5. Prawne formy działania administracji, red. R. Hauzer, Z. Niewiadomski, A. Wróbel, Warszawa 2011, s. $77-218$.

12 Kryteria te na podstawie literatury obejmują: ,jednostronność działania administracji, domniemanie prawidłowości podjętych przez administrację działań oraz przymus bądź dopuszczalność zastosowania przymusu w celu wymuszenia respektowania nakazów czy zakazów płynących z działań administracji publicznej”. Tak K.M. Ziemski, Podstawy problematyki, [w:] System Prawa Administracyjnego, t. 5, s. 53.

13 Tak K.M. Ziemski, Indywidualny akt..., s. 137.

14 W przypadku niewładczych form działania ,pozycja organu administracji i pozycja drugiego podmiotu stosunku prawnego są sobie równe lub - jeżeli występuje tu pewne zróżnicowanie — to jednak organ administracji nie zajmuje pozycji zdecydowanie nadrzędnej, jak ma to miejsce w przypadku działań w formach władczych". Tak M. Wierzbowski, A. Wiktorowska, Prawne formy działania administracji, [w:] Prawo administracyjne, red. M. Wierzbowski, Warszawa 2017, s. $270-271$. 
publicznej wiadomości przez ogłoszenie w Dzienniku Urzędowym NBP lub przez zamieszczenie na stronie internetowej (art. 12 ust. 5 u.n.m.). Już we wstępie należy zaznaczyć, że tego typu formy prawne działania w świetle powyższych ustaleń nie mogą być zaliczane do źródeł prawa powszechnie obowiązujące go i nie mogą być podstawą do wydawania indywidualnych aktów objętych przymusem administracyjnym.

\section{PRAWNE FORMY DZIAŁANIA STOSOWANE W NADZORZE MAKROOSTROŻNOŚCIOWYM - PERSPEKTYWA PORÓWNAWCZA}

Interesujących wniosków może dostarczyć perspektywa prawnoporównawcza dotycząca charakteru prawnych form działania stosowanych w procesie kształtowania polityki makroostrożnościowej. Federalny Komitet ds. Stabilności (Ausschuss für Finanzstabilität - AFS) ${ }^{15}$, powołany do życia w 2013 roku na podstawie ustawy o stabilności finansowej (Finanzstabilitätsgesetzes - FinStab$\mathrm{G})^{16} \mathrm{~W}$ ramach przyjętego w Niemczech rozwiązania organizacyjnego, nie jest organem administracji, lecz komitetem wewnętrznym w strukturach Federalnego Ministerstwa Finansów. W konsekwencji nie ma własnych i bezpośrednich kompetencji do kształtowania regulacji normatywnych, gdyż te - zgodnie z modelowym rozwiązaniem przyjętym w Niemczech dla całego rynku finansowego (w tym sektora bankowego) - realizowane są przez Federalny Urząd Nadzoru nad Rynkiem Usług Finansowych (Bundesanstalt für Finanzdienstleitungsaufsicht - BaFin $)^{17}$. W celu przeciwdziałania zaobserwowanym zagrożeniom stabilności finansowej AFS może jednak wydawać publiczne lub poufne ostrzeżenia i zalecenia skierowane zarówno do BaFin (realizującego również nadzór mikroostrożnościowy), jak i rządu federalnego lub innych organów publicznych w Niemczech między innymi w kwestii konieczności podjęcia pożądanych działań przez te podmioty.

W przypadku Wielkiej Brytanii ${ }^{18}$ zadania w zakresie nadzoru i polityki makroostrożnościowej realizuje Komitet Polityki Finansowej (Financial Policy Committee - FPC) związany funkcjonalnie i organizacyjnie z Bankiem An-

15 Szerzej na ten temat Ausschuss für Finanzstabilität, Erster Bericht an den Deutschen Bundestag zur Finanzstabilität in Deutschland, AFS, Juni 2014, http://www.bundesfinanzministerium. de/ Content/DE/Downloads/Abt_7/2014-06-18-Bericht-AFS.pdf?_blob= publicationFile\&v=4 (dostęp: 4.08.2018).

16 Ustawa z dnia 28 listopada 2012 roku o stabilności finansowej (Finanzstabilitätsgesetzes), (BGBl. I, s. 2369), dalej: FinStabG.

17 Działający na podstawie ustawy z dnia 22 kwietnia 2002 roku w sprawie organu nadzoru nad rynkiem usług finansowych (Finanzdienstleistungsaufsichtsgesetz), tekst w wersji zmienionej z 1 stycznia 2014 r., (BGBl. I, s. 306).

18 Szerzej na ten temat M. Ochwat, Nadzór finansowy w Wielkiej Brytanii, „Monitor Prawa Bankowego" 2016, nr 9 (70), s. 46-65. 
glii (Bank of England), który w myśl sekcji 9A Bank of England Act $1998^{19}$ ma szeroki mandat w zakresie polityki stabilności finansowej ${ }^{20}$. Uprawniony jest do wydawania wskazówek (directions) oraz rekomendacji (recommendations). Pierwsza forma skierowana jest wyłącznie do pozostałych organów odpowiedzialnych za nadzór ostrożnościowy i określa wymogi, jakie powinny one spełniać, aby zapewnić realizację środków makroostrożnościowych w odniesieniu do określonej kategorii podmiotów regulowanych (sekcja 9H B.E.a.). Natomiast rekomendacje, w myśl sekcji 9O-9R B.E.a., mogą być skierowane zarówno do instytucji rynku finansowego, i dotyczyć na przykład wykonywania przez Bank jego funkcji w odniesieniu do systemów płatniczych, systemów rozliczeniowych oraz do izb rozliczeniowych, jak i do Ministerstwa Skarbu (the Treasury) między innymi w kwestii wykonywania jego kompetencji w zakresie wydawania środków makroostrożnościowych czy określania działalności regulowanej. Ponadto ich adresatem mogą być mikroostrożnościowe organy nadzoru.

We Francji funkcję nadzoru makroostrożnościowego pełni Wysoka Rada ds. Stabilności Finansowej (Le Haut Conseil de stabilité financière - HCSF), której głównym celem jest „nadzorowanie systemu finansowego jako całości w celu zagwarantowania jego stabilności i zapewnienia trwałego udziału sektora finansowego we wzroście gospodarczym" (art. L.631-2-1 Code monétaire et financier ${ }^{21}$ ). W zakresie zadań HCSF w myśl art. L.631-2-1 c.m.f. mieszczą się między innymi: zapewnienie współpracy i wymiany informacji pomiędzy zaangażowanymi instytucjami oraz określenie i ocena charakteru oraz zakresu ryzyka systemowego wynikającego z sytuacji sektora i rynków finansowych. Tym, co wyróżnia francuskie rozwiązanie modelowe na tle pozostałych, są kompetencje regulacyjne HCSF obejmujące zarówno opinie lub zalecenia ${ }^{22}$, które sui generis pozbawione są charakteru władczego, lecz ukierunkowane na kształtowanie dyscypliny poprzez możliwość podawania ich do wiadomości publicznej, jak i przewidziane możliwości władczego kształtowania regulacji normatywnych w zakresie między innymi środków makroostrożnościowych, takich jak: bufor antycykliczny ${ }^{23}$ czy bufor ryzyka systemowego, stosowanych na wniosek guber-

19 Ustawa z dnia 23 kwietnia 1998 roku o Banku Anglii (Bank of England Act 1998), (1998, c. 11), dalej: B.E.a.

20 FPC jest odpowiedzialna za identyfikację, monitorowanie oraz podejmowanie działań zmierzających do ograniczania ryzyka systemowego w celu ochrony i wzmocnienia odporności systemu finansowego w Wielkiej Brytanii (sekcja 9C (2) B.E.a.).

21 Ustawa z dnia 14 grudnia 2000 roku Kodeks pieniężny i finansowy (Code monétaire et financier) — aneks do ustawy nr 2000-1223 w kształcie nadanym przez ustawę 2014-158 z 20.02.2014 roku (J.O. nr 29 z dnia 17 grudnia 2000 roku), dalej: C.m.f.

22 Szerzej na temat zestawu uprawnień regulacyjnych HCSF oraz przesłanek ich zastosowania: Stratégie du Haut Conseil de stabilité financière, HCSF, s. 6-9, https://www.economie.gouv.fr/ files/strategie_macroprudentielle_du_hcsf.pdf (dostęp: 5.03.2018).

23 Przykładowo: Décision n ${ }^{\circ}$ D-HCSF-2017-3 du 30 septembre 2017 relative au taux du coussin de fonds propres contracyclique. 
natora Banku Francji, a także możliwości ustalania w sposób normotwórczy warunków udzielania kredytów przez instytucje podlegające nadzorowi.

Podobny charakter mają również środki stosowane do kształtowania polityki i nadzoru ostrożnościowego na poziomie Unii Europejskiej w kontekście działalności Europejskiego Banku Centralnego i związanej z nim Europejskiej Rady ds. ryzyka systemowego (ERRS). W myśl rozporządzenia UE nr 1092/201024 ma ona kompetencje do wydawania ostrzeżeń i zaleceń ${ }^{25}$, które mogą mieć charakter ogólny lub szczegółowy. Stosowanie się adresatów do tego typu form opiera się na mechanizmie „zastosuj lub wyjaśnij” (act or explain) i jest przykładem niewładczego instrumentu oddziaływania na sferę publiczną oraz kształtowania dyscypliny rynkowej wśród instytucji ${ }^{26}$, przy czym zakres zastosowania lub jego braku jest przedmiotem oceny wdrożenia w postaci oficjalnego raportu ${ }^{27}$ i może być przedmiotem dalszego postępowania ${ }^{28}$. Należy podkreślić, że tego typu formy prawne nie mają wiążącego charakteru wobec braku możliwości „narzucania swojej woli innym", co skutkuje zaliczeniem ich w piśmiennictwie do sfery tak zwanego prawa miękkiego (soft law) ${ }^{29}$.

W Polsce do kategorii prawa miękkiego można zaliczyćc ${ }^{30}$ przede wszystkim rekomendacje wydawane przez $\mathrm{KNF}^{31}$. Ta ugruntowana w art. 137

24 Rozporządzenie Parlamentu Europejskiego i Rady (UE) nr 1092/2010 z dnia 24 listopada 2010 roku w sprawie unijnego nadzoru makroostrożnościowego nad systemem finansowym i ustanowienia Europejskiej Rady ds. Ryzyka Systemowego, (Dz. Urz. UE L 331 z 15.12.2010, s. 1).

25 Ich adresatami mogą być: UE jako całość, jedno lub więcej państw członkowskich, organ lub organy nadzoru na poziomie europejskim albo organ lub organy nadzoru na poziomie krajowym.

26 Za przykład omawianej kwestii może posłużyć zalecenie Europejskiej Rady ds. Ryzyka Systemowego z dnia 22 grudnia 2011 roku w sprawie mandatu makroostrożnościowego organów krajowych (ERRS/2011/3), (Dz. Urz. UE C 41 z 14.2.2012, s. 1).

27 ESRB: Recommendation on the macro-prudential mandate of national authorities (ESRB/2011/3), Follow-up Report - Overall assessment, June 2014, s. 11, https:/www.esrb.europa.eu/pub/pdf/recommendations/2014/ ESRB_2014.en.pdf?600ec3fed1d5300e6a16ef0767b75cc5 (dostęp: 15.08.2018).

28 Jeżeli zostanie stwierdzone, że zalecenie nie było zrealizowane, a adresatom nie uda się tego wyjaśnić w odpowiedni sposób, wtedy ERRS informuje o tym Radę oraz w stosownych przypadkach - zainteresowane organy nadzoru europejskiego (art. 17 rozp. o ERRS).

29 Tak E. Ferran, K. Alexander, Can soft law bodies be effective? Soft systemic risk oversight bodies and the special case of the European systemic risk board, „Legal Studies Research Paper Series" 36, 2011, s. 33.

30 Tak też M. Jabłoński, Krajowe źródła prawa administracyjnego, [w:] Prawo administracyjne, red. M. Wierzbowski, Warszawa 2017, s. 49.

31 Szerzej na temat rekomendacji J.A. Krzyżewski, Rekomendacje nadzorcze - charakter prawny i zakres mocy obowiazującej, „Prawo Bankowe” 2000, nr 7-8, s. 110-121; T. Czech, Charakter prawny rekomendacji Komisji Nadzoru Finansowego, „Przegląd Prawa Publicznego” 2009, nr 11, s. 63-80; M. Olszak, Rekomendacje organu nadzoru bankowego - geneza, przedmiot regulacji, charakter prawny, „Przegląd Ustawodawstwa Gospodarczego” 2010, nr 11, s. 2-11; B. Smykla, Prawo bankowe. Komentarz, Warszawa 2011, s. 552-553; K. Kohutek, [w:] Prawo bankowe. Komentarz, t. 2, red. F. Zoll, Kraków 2005, s. 496-498. 
ust. 1 pkt 5 u.p.b. ${ }^{32}$ forma prawna wywiera znaczny wpływ na zachowania uczestników sektora bankowego. Rekomendacje KNF zawierają „normy zalecanego, rekomendowanego [...] postępowania, których przestrzeganie nie może być jednak egzekwowane poprzez zastosowanie przymusu państwowego"33, a zatem są niewiążące dla adresatów i w tym kontekście należy zaliczyć je do niewładczych form działania administracji ${ }^{34}$. Z drugiej strony mogą one „wywoływać praktyczne skutki” oraz „mają na celu wpływanie na zachowanie adresatów"35 i w tym kontekście pełnią istotną rolę w kształtowaniu zachowań adresatów poprzez oddziaływanie na ich dyscyplinę rynkową. Tego typu działalność polega na kształtowaniu pewnych oczekiwanych „standardów postępowania”, którym podporządkowanie może być „odpowiednio premiowane” i w tym sensie ,stanowi przejaw samozwiązania i ograniczenia się przez organ administracji publicznej"36.

\section{STANOWISKA KSF}

W Polsce Komitet Stabilności Finansowej, w myśl art. 17 u.n.m. może wydawać stanowiska (dalej: stanowiska KSF) w przypadkach identyfikacji źródła ryzyka systemowego w systemie finansowym lub jego otoczeniu. Ich adresatami mogą być zarówno:

a) „właściwe podmioty”, czyli członkowie Komitetu: KNF, minister finansów, NBP i $\mathrm{BFG}^{37}$, lub

b) ogół podmiotów tworzących system finansowy lub jego część, w tym zarządzających produktami lub wykorzystujących infrastruktury rynkowe.

Stanowiska KSF na podstawie dorobku doktryny prawa administracyjnego, można zdefiniować jako: akty wiedzy o charakterze jednostronnym, ,potwierdzające zaistnienie stanu faktycznego lub prawnego", wydane w oparciu o posiadane ,zasoby informacji” oraz „po przeprowadzeniu innych badań [...], innych czynności sprawdzających, czyli po zdobyciu odpowiedniej wiedzy"38.

32 Aktualnie kompetencje KNF w tym zakresie określa art. 137 ust. 1 pkt 5 u.p.b., uprawniający nadzorcę do wydawania ,rekomendacji dotyczących dobrych praktyk ostrożnego i stabilnego zarządzania bankami".

33 Tak M. Olszak, op. cit., s. 8.

34 Podobnie ibidem, s. 9; T. Czech, op. cit., s. 74.

35 Tak M. Jabłoński, op. cit., s. 50.

36 Tak ibidem.

37 W myśl ustawy z dnia 10 czerwca 2016 roku o Bankowym Funduszu Gwarancyjnym, systemie gwarantowania depozytów oraz przymusowej restrukturyzacji (tekst jedn. Dz. Urz. z $2017 \mathrm{r}$. poz. 1937, dalej: u.BFG) „Fundusz jest osobą prawną” (art. 3 ust. 1), przy czym „nie jest państwową osobą prawną i nie jest jednostką sektora finansów publicznych" (art. 3 ust. 3).

38 Forma ta w swojej istocie jest zbliżona do aktów wydawanych pod nazwą zaświadczeń lub poświadczeń zaliczanych do czynności materialno-technicznych administracji. Tak M. Stahl, 
W tym świetle stanowiska KSF proponuje określać jako akty wiedzy o zaistnieniu zjawiska ryzyka systemowego, wydawane w efekcie przeprowadzanej w sposób ciągły działalności monitorującej i analitycznej ukierunkowanej na jego identyfikację. W kontekście użytego nazewnictwa analogiczną funkcję $\mathrm{w}$ innych państwach (np. Niemcy, Wielka Brytania), pełnią „ostrzeżenia” i co ciekawe tego typu nazewnictwo było proponowane również w Polsce na wczesnym etapie prac parlamentarnych ${ }^{39}$.

W nawiązaniu do celu nadzoru makroostrożnościowego, tego typu formy ukierunkowane są przede wszystkim na komunikację ${ }^{40}$, która pozwala wszystkim uczestnikom systemu finansowego poznać znaczenie tej polityki oraz ma przygotować rynek na wypadek potrzeby interwencji, a zatem ze swojej natury powinna wyprzedzać inne formy prawne, które mają charakter wiążący. Tego typu uwaga ma szczególne znaczenie w przypadku kształtowania regulacji makroostrożnościowej, która w wysokim stopniu może być „podatna” na dyskrecjonalność działania, gdyż prawidłowa „kalibracja instrumentów zależy od rodzaju szoku, tempa narastania ryzyka i wielu innych parametrów", a regulator ma „silny bodziec, aby stosować (w tym procesie) metodę prób i błędów”41. Należy pamiętać przy tym, że każdorazowa zmiana tego typu parametrów wymaga dostosowania działania instytucji finansowych, w tym przede wszystkim banków, a konsekwencje tego procesu odczuwalne są w tak zwanym sektorze realnym gospodarki po stronie konsumentów i przedsiębiorców i mogą skutkować między innymi wyższymi kosztami dostępu do usług finansowych. Stąd kluczowa rola właściwej komunikacji i wyznaczania przewidywalnych dla adresatów reguł poruszania się władz publicznych - KSF i ministra finansów jako regulatora.

Na tym tle odmienny charakter będą mieć stanowiska wydawane przez KNF, które w świetle ustaleń doktrynalnych zbliżone są do niejednolitej kategorii „aktów wykładni”42 mających na celu wyznaczanie konsekwencji prawnych i wiązanych bardziej ze stosowaniem prawa. W świetle poglądów doktryny,

Szczególne prawne formy działania administracji, [w:] System Prawa Administracyjnego, t. 5, s. $382-383$.

39 Na początkowym etapie prac legislacyjnych dla realizacji nadzoru i polityki makroostrożnościowej zakładano powołanie Rady ds. Ryzyka Systemowego, uprawnionej do wydawania ostrzeżeń skierowanych do „właściwych podmiotów” oraz fakultatywnie do „rynku finansowego lub jego części” w przypadku identyfikacji ryzyka w systemie (art. 16). Zob. Projekt ustawy o nadzorze makroostrożnościowym nad systemem finansowym z dnia 3 stycznia 2014 roku, https://legislacja.rcl. gov.pl/docs//2/170282/170290/170297/dokument97902.pdf (dostęp: 2.08.2018).

40 Szerzej na ten temat Objective-setting and communication of macroprudential policies, Raport, BIS, CGFS Papers, nr 57, http:/www.bis.org/publ/cgfs57.pdf (dostęp: 30.08.2019).

41 Tak D.K. Rosati, op. cit., s. 397.

42 Szerzej na ten temat E. Bojanowski, E. Kaszubowski, Urzędowe akty wyktadni w sferze prawa powszechnego a formy działania administracji publicznej (wybrane formy), [w:] Nowe problemy badawcze $w$ teorii prawa administracyjnego, red. J. Boć, A. Chajbowicz, Wrocław 2009, s. 155-161; M. Stahl, op. cit., s. 385-389. 
W odróżnieniu od prawa miękkiego (soft law) nie tworzą one „nowych reguł czy standardów postępowania”, lecz jedynie stanowią „wyjaśnienie obowiązujących przepisów prawa" ${ }^{43}$, co przemawiać ma za wykluczeniem ich z tej kategorii. Jak wynika z przytoczonego przykładu, stanowiska mogą również dotyczyć materii nadzoru ostrożnościowego na użytek stosowania regulacji krajowych i UE, w tym w zakresie stosowania przez banki współczynników kapitałowych w odniesieniu do buforów kapitałowych ${ }^{44}$. W konkluzji stanowiska KNF nie mają podstaw ustawowych i przybierają charakter aktów niewiążącej interpretacji, wydawanych w niesformalizowany sposób, zawierających wytyczne i instrukcje dotyczące stosowania norm prawnych istniejących na podstawie oddzielnych aktów (ustaw, rozporządzeń, regulacji UE).

\section{REKOMENDACJE KSF}

Kolejną prawną formą stosowaną w procesie nadzoru ostrożnościowego bezpośrednio przez KSF są rekomendacje (dalej: rekomendacje KSF), które mogą być wydawane, gdy zachodzi konieczność podjęcia działań w celu ograniczenia ryzyka systemowego, skierowane wyłącznie do członków $\mathrm{KSF}$, czyli tak zwanych właściwych podmiotów. Instytucje te zobowiązane są do podjęcia rekomendowanych działań lub wyjaśnienia przyczyn ich niepodjęcia (art. 18 u.n.m.).

Formy prawne wykorzystujące tę samą nazwę, wydawane przez KSF, mają zasadniczo odmienny charakter prawny. W założeniu rekomendacja KSF ma instruować i kreować określone oraz pożądane przez Komitet zachowania po stronie ich adresatów. Rekomendacje KSF wzorem analogicznych prawnych form nadzoru stosowanych w innych państwach UE, a w odróżnieniu od formy stosowanej przez KNF, są wzmocnione mechanizmem (comply or explain) ukierunkowanym na oddziaływanie poprzez kształtowanie dyscypliny rynkowej. Adresaci zobowiązani są do podjęcia rekomendowanych działań lub wyjaśnienia przyczyn ich niepodjęcia, jednakże rekomendacje KSF w odróżnieniu od - wydawałoby się podobnych — form stosowanych w porównywanych systemach prawnych (Niemcy, Francja, Wielka Brytania) skierowane są wyłącznie do tak zwanych właściwych podmiotów, a pomijają innych uczestników systemu finansowego, czyli instytucje finansowe, instytucje infrastruktury rynku, o których mowa choćby w art. 17 u.n.m. Przykładowo w Niemczech rekomendacje wydawa-

43 Por. M. Jabłoński, op. cit., s. 50.

44 Stanowisko KNF w sprawie minimalnych poziomów współczynników kapitałowych z 24 listopada 2017 roku wydane w związku z wejściem w życie 1 stycznia 2018 roku rozporządzenia Ministra Rozwoju i Finansów z dnia 1 września 2017 roku w sprawie bufora ryzyka systemowego (Dz.U. z 2017 r. poz. 1776). Komisja Nadzoru Finansowego (KNF) wskazuje wysokości minimalnych poziomów współczynników kapitałowych obowiązujących banki w 2018 roku. 
ne przez AFS mogą dotyczyć między innymi materii nowych instrumentów skierowanych do rynku kredytowego ${ }^{45}$. Ogranicza to donośność rekomendacji KSF i determinuje charakter prawny tego typu form, gdyż spostrzeżenia dotyczące rekomendacji jako efektywnej formy prawnej kształtowania zachowań rynkowych (wydawanych przez KNF) nie mają odniesienia do formy prawnej o tej samej nazwie stosowanej przez KSF. Co prawda obydwie formy łączy niewładczy charakter, jednakże rekomendacje KSF (nadzór makroostrożnościowy) są skierowane wyłącznie do członków KSF, czyli szerokiej kategorii organów sprawujących administrację, co w istocie zbliża je do aktów stosowanych w szeroko rozumianej sferze wewnętrznej administracji ${ }^{46}$, przy czym nie zachodzą w tym wypadku przesłanki podległości hierarchicznej, jak również zróżnicowany jest status prawny samych adresatów. Funkcjonowanie w systemie nadzoru dwóch z gruntu odmiennych form prawnych może prowadzić do pewnych konfuzji pojęciowych, co zdaje się dostrzegano w pierwotnym projekcie regulacji, w której używano właściwszej nie tylko w znaczeniu semantycznym konstrukcji ,zalecenia” 47 .

W tym kontekście rekomendacje KSF zbliżone są bardziej do kategorii aktów prawa wewnętrznego ${ }^{48}$. To spostrzeżenie znajduje swoje uzasadnienie w kontekście ukształtowania składu KSF, w którym zasiadają wszyscy potencjalni adresaci zaangażowani w realizację celu nadzoru makroostrożnościowego (art. 1 ust 2. u.n.m.), a zatem pomiędzy Komitetem a adresatami występuje więź funkcjonalna ${ }^{49} \mathrm{~W}$ zakresie kształtowania polityki i środków ostrożnościowych na poziomie makro- i mikroostrożnościowym. W świetle wypowiedzi doktryny należy uściślić, że spora grupa aktów wewnętrznych, jak między innymi zalecenia,

45 Zob. Empfehlung AFS/2015/1 vom 30. Juni 2015 zu neuen Instrumenten für die Regulierung der Darlehensvergabe zum Bau oder Erwerb von Wohnimmobilien, https://www.bundesfinanzministerium.de/Content/DE/Pressemitteilungen/Finanzpolitik/2015/06/2015-06-30-PM22empfehlung. pdf?_blob=publicationFile\&v=4 (dostęp: 7.08.2018).

46 Zob. K.M. Ziemski, Podstawy problematyki..., s. 48-51.

47 W myśl art. 17 projektu proponowana Rada ds. Ryzyka Systemowego mogła kierować do „właściwych podmiotów” zalecenia „wskazujące konieczność podjęcia prze nie działań służących ograniczeniu ryzyka systemowego". Zob. Projekt ustawy o nadzorze makroostrożnościowym nad systemem finansowym z dnia 3 stycznia 2014 roku, https://legislacja.rcl.gov.pl/ $\operatorname{docs} / / 2 / 170282 / 170290 / 170297 /$ dokument97902.pdf (dostęp: 2.08.2018).

48 Szerzej na ten temat: A. Bałaban, Akty normatywne wewnętrznie obowiąujace, [w:] Konstytucyjny system źródeł prawa w praktyce, red. A. Szmyt, Warszawa 2005, s. 95-107; W. Płowiec, Koncepcja aktu prawa wewnętrznego w Konstytucji RP, Poznań 2006; L. Garlicki, Konstytucyjne źródta prawa administracyjnego, [w:] System Prawa Administracyjnego, t. 2. Konstytucyjne podstawy funkcjonowania administracji publicznej, red. R. Hauzer, Z. Niewiadomski, A. Wróbel, Warszawa 2012, s. 77-83; A. Błaś, Formy prawne w sferze działań wewnętrznych administracji publicznej, [w:] System Prawa Administracyjnego, t. 5, s. 279-294; A. Adamczyk, Publicznoprawne formy działania administracji. Teoria i praktyka, Warszawa 2013, s. 47-74.

49 Zob. wyrok TK z 1 grudnia 1998 roku, sygn. K21/98, OTK 1998, nr 7, poz. 116, oraz wyrok TK z 28 czerwca 2000 roku, sygn. K25/99, OTK 2000, nr 5, poz. 141.

Przegląd Prawa i Administracji 115, 2018

(C) for this edition by CNS 
okólniki, pisma czy instrukcje ${ }^{50}$, nie może być zaliczana do katalogu form prawnych w rozumieniu art. 93 Konstytucji $\mathrm{RP}^{51}$, zarezerwowanych dla „źródeł prawa” mających charakter normatywny ${ }^{52}$, pomimo otwartego charakteru ich katalogu (w znaczeniu podmiotowym i przedmiotowym ${ }^{53}$. Omawiane formy, jak rekomendacje KSF, stanowią kategorię odrębną od źródeł prawa powszechnie obowiązującego i nie mogą stanowić podstawy do wydawania decyzji, czyli indywidualnych aktów prawnych kształtujących sytuację prawną adresatów ${ }^{54}$, aczkolwiek znane są przypadki tak zwanego refleksu na zewnątrz ${ }^{55}$ i pośredniego wpływu na zachowania podmiotów znajdujących się na zewnątrz struktury administracji. W materii nadzoru ostrożnościowego zjawisko to również może potencjalnie wystąpić, gdy przedmiot rekomendacji będzie dotyczyć pośrednio zachowań, praktyk, dostępności usług świadczonych przez instytucje infrastruktury, instytucje finansowe, a finalnie - uczestników indywidualnych rynku. W tym kontekście warto zwrócić uwagę na użycie przez ustawodawcę w art. 18 ust. 1 u.n.m. sformułowania, że KSF przy zastosowaniu rekomendacji „wskazuje konieczność podjęcia przez te podmioty działań". Nie ma możliwości prawnie wiążącego wpływania na działalność adresatów, co sugeruje konstrukcja zawarta w art. 18 ust. 3 u.n.m. i niejako potwierdza po stronie adresata art. 24 ust. 2 u.n.m., w myśl którego minister właściwy do spraw instytucji finansowych ocenia co kwartał wysokość wskaźnika bufora antycyklicznego, „biorąc pod uwagę rekomendację Komitetu”.

W konsekwencji omawiane formy nie są „aktami dyrektywnymi”, lecz mają raczej „charakter indykatywny”, przy czym źródło ich przestrzegania nie wynika z układów kierownictwa na ogół spotykanych w administracji ${ }^{56}$, lecz odbywa się poprzez kształtowanie dyscypliny rynkowej i wynika z autorytetu KSF oraz podstaw faktycznych uzasadniających wydanie rekomendacji, do których adresat musi się merytorycznie ustosunkować w przypadku podjęcia działania niezgodnego z intencją Komitetu, co znacznie zawęża potencjalne zjawisko „luzu decyzyjnego". Co prawda z reguły użyte nazewnictwo nie przesądza jeszcze o kwalifikacji danej formy, jednakże w tym wypadku używane w pierwotnym

50 Przykładowo: J. Jeżewski, Wewnętrzne prawo administracyjne, [w:] Prawo administracyjne, red. J. Boć, Wrocław 2003, s. 47-49, W. Płowiec, op. cit., s. 47; A. Adamczyk, op. cit., s. 64-65.

51 Zob. wyrok TK z dnia 20 października 1998 roku, sygn. akt K 7/98, OTK nr 6, 1998, poz. 96; oraz wyrok TK z 1 grudnia 1998 roku, sygn. akt K 21/98, OTK ZU 1998, nr 7, poz. 116.

52 Por. A. Bałaban, op. cit., s. 98; W. Płowiec, op. cit., s. 77; L. Garlicki, op. cit., s. 78; K. Popik-Chorąży, Legislacja administracyjna, Warszawa 2013, s. 161-162.

53 Por. J. Mielczarek, Otwarty katalog aktów prawa wewnętrznego a zasada zaufania do władz publicznych, [w:] Sprawiedliwość i zaufanie do władz publicznych w prawie administracyjnym, red. M. Stahl, M. Kasiński, K. Wlaźlak, Warszawa 2015, s. 372-382.

54 Zob. wyrok TK z 11 maja 2004 roku, sygn. akt K 4/03, OTK ZU 2004, nr 5/A, poz. 41.

55 Zob. W. Płowiec, op. cit., s. 50 i literatura tam przytaczana.

56 Por. J. Jeżewski, op. cit., s. 49. 
projekcie nazewnictwo „zalecenia"57, bardziej oddaje skądinąd niewładczy charakter prawny tej formy. Rekomendacje KSF w kształcie nadanym u.n.m. najbardziej zbliżone są do kategorii aktów współdziałania (koordynacji), stosowanych w różnych działaniach w administracji, między innymi w przypadku „tworzenia wspólnych organów o mieszanym składzie”, gdzie ze względu na „samodzielność podmiotów administrujących — nie może przybierać władczych form" 58 .

Podsumowując, należy podkreślić, że prawna forma rekomendacji KSF jawi się de facto jako wewnątrzadministracyjny akt skierowany do innego organu uczestniczącego w tym procesie (minister finansów, NBP, KNF) lub BFG (powołanego ustawowo ${ }^{59}$ między innymi do prowadzenia systemu gwarantowania depozytów, realizującego tym samym funkcje zlecone z zakresu administracji), a zatem wykorzystywany wyłącznie w sferze publicznej.

\section{OPINIE}

Kompetencje KSF do wydawania opinii przewidziano zarówno w u.n.m., jak i innych aktach regulujących indywidualne uprawnienia instytucji zaangażowanych w składzie KSF w zakresie oceny ich wpływu na ryzyko systemowe. Przypadki wydawania opinii przez KSF można podzielić na trzy grupy:

1. regulacji ostrożnościowych, czyli szeroko rozumianych aktów prawnych wydawanych przez inne organy między innymi w sprawach: rozporządzeń ministra finansów, w rozumieniu art. 4 pkt 8 u.n.m., dotyczących na przykład kształtowania buforów, o których mowa w art. 39 ust. 3 u.n.m. czy rekomendacji KNF odnoszących się do aspektów makroostrożnościowych art. 137 ust. 2 u.p.b.;

2. środków mikroostrożnościowych stosowanych w formie decyzji administracyjnych wydawanych przez Komisję Nadzoru Finansowego (która działa w tym wypadku jako organ nadzoru mikroostrożnościowego) w sprawach indywidualnych dotyczących: określenia globalnych instytucji o znaczeniu systemowym - GSII (art. 35 ust. 1 i 2 u.n.m.) oraz innych niż globalne instytucji o znaczeniu systemowym - OSII) (art. 39 ust. 1 u.n.m.);

57 W myśl art. 17 projektu proponowana Rada ds. Ryzyka Systemowego mogła kierować do „właściwych podmiotów” zalecenia „wskazujące konieczność podjęcia prze nie działań służących ograniczeniu ryzyka systemowego". Zob. Projekt ustawy o nadzorze makroostrożnościowym nad systemem finansowym z dnia 3 stycznia 2014 roku, https://legislacja.rcl.gov.pl/ docs//2/170282/170290/170297/dokument97902.pdf (dostęp: 12.08.2018).

58 Tak M. Stahl, op. cit., s. 359.

59 BFG jest osobą prawną wykonującą zadania określone w ustawie (art. 3 ust. $1 \mathrm{u}$. BFG), a jego statut, który określa szczegółowo jego cele oraz zadania, organizację oraz zasady tworzenia i wykorzystywania funduszy własnych, nadaje w drodze rozporządzenia minister właściwy do spraw instytucji finansowych (art. 3 ust. 4 u. BFG). 
3. wielu innych przypadków regulowanych w ustawach sektorowych, gdy o opinie mogą wnioskować na przykład KNF — w przypadkach zatwierdzania planu naprawy banku i oceny wpływu jego upadłości na rynek (art. 141p ust. 3 u.p.b.) czy BFG - na przykład w materii oceny wpływu zastosowania planów przymusowej restrukturyzacji na poziom ryzyka systemowego (art. 95 ust. 3 u.BFG).

Wydawanie opinii odbywa się w trybie przewidzianym w art. 106 ustawy Kodeks postępowania administracyjnego ${ }^{60}$, do którego w określonych przypadkach odsyła „wprost” u.n.m., przy czym dotyczy to wyłącznie opinii poprzedzających decyzje wydawane przez KNF odnośnie do stosowania środków mikroostrożnościowych (drugi obszar). W tym zakresie przedmiotowym odbywa się to w formie postanowienia wydawanego nie później niż w terminie dwóch tygodni od dnia doręczenia żądania, które może poprzedzać postępowanie wyjaśniające. Gdy wnioskodawcą jest KNF, przyjmuje się zasadę, że na postanowienie nie służy zażalenie, a decyzje administracyjne podjęte na ich podstawie są natychmiast wykonalne. Zatem zgodnie z ogólną zasadą z art. 142 k.p.a. możliwość jej wzruszenia dopuszczalna jest jedynie na drodze odwoławczej, a w omawianych sytuacjach w formie wniosku o ponowne rozpatrzenie sprawy (art. $127 \S 3$ k.p.a. w zw. z art. 11 ust. 6 u.n.f.).

Co istotne z punktu widzenia systemowego i co wynika z ukształtowania formy prawnej opinii — wnioskodawca nie jest związany jej treścią, a zatem może ją uwzględnić w całości, w części albo nie uwzględnić w ogóle. Ponadto pomimo koncepcyjnego zorganizowania KSF jako miejsca analizy to KNF ma indywidualne uprawnienia do „oceny” znaczenia systemowego instytucji GSII i OSII, przy czym wydaje się, że decyzje administracyjne będące efektem tego procesu mają charakter związany, gdyż zakres swobody organu ograniczony jest obowiązkiem uwzględnienia wytycznych Europejskiego Urzędu Nadzoru Bankowego oraz opinią KSF, co potwierdza sama KNF w stosownym komunikacie ${ }^{61}$.

Użycie przez ustawodawcę formy prawnej opinii stosowanej na wniosek zainteresowanych podmiotów sugeruje, że ich celem jest nie samo zagwarantowanie bezpośredniego wpływu KSF na kształtowanie treści, między innymi instrumentów mikroostrożnościowych KNF (gdyż takich możliwości w świetle wszystkich omawianych kompetencji ów Komitet nie ma) czy nawet akcentowanie potrzeby uzyskania spójności i komplementarności stosowanych środków na obydwu poziomach nadzoru ostrożnościowego (taki cel mają przedmiotowe rekomendacje), lecz w istocie chodzi tutaj o merytoryczną i prewencyjną ocenę przez K SF szczegółowych działań, które mogą wywołać narastanie ryzyka systemowego.

60 Ustawa z dnia 14 czerwca 1960 roku Kodeks postępowania administracyjnego (tekst jedn. Dz. Urz. z 2018 r. poz. 2096), dalej: k.p.a.

61 KNF: Identyfikacja innych instytucji o znaczeniu systemowym, 14 listopada 2016 roku, Warszawa, https://www.knf.gov.pl/knf/pl/komponenty/img/instytucje_o_znaczeniu_systemowym_ OSII_14_11_2016_54988.pdf (dostęp: 9.08.2018). 


\section{KOMPETENCJE KSF A POZOSTAŁE PRAWNE FORMY PRZEWIDZIANE W U.N.M.}

Można zaobserwować pewną prawidłowość, że kształtowanie analogicznych — określonych w pakiecie regulacji CRR i CRD IV — parametrów nadzoru makroostrożnościowego w wielu różnych systemach prawnych odbywa się na podstawie aktów normatywnych ${ }^{62}$. Co charakterystyczne dla procesów regulacji w Polsce, ustawodawca posługuje się formą prawną rozporządzeń ${ }^{63}$, zawierających normy powszechnie obowiązujące, będące jednocześnie podstawą do wydawania aktów indywidualnych. Ogólna odpowiedzialność za funkcję regulacji makroostrożnościowej spoczywa na ministrze finansów w rozumieniu art. 4 pkt 8 u.n.m., czyli odpowiednio: ministrze właściwym do spraw budżetu, ministrze właściwym do spraw finansów publicznych lub ministrze właściwym do spraw instytucji finansowych. Poza zakresem podmiotowym uprawniającym do stosowania rozporządzeń znajdują się wszystkie pozostałe organy administracji publicznej zaangażowane w składzie KSF, w tym również NBP, który bezsprzecznie zaliczany jest do kategorii konstytucyjnych centralnych organów państwa ${ }^{64}$. Minister finansów pełni funkcję organu wyznaczone go (DA), realizując kompetencje do kształtowania treści normatywnych w przypadkach: określania wysokości bufora antycyklicznego - $\mathrm{CCyB}^{65}$ (na podstawie art. 24 ust. 3 u.n.m), bufora ryzyka systemowego - SRB (na podstawie art. 50 ust. 8 i art. 53 ust. 2 u.n.m.) oraz tak zwanych środków krajowych z art. 458 CRR (na podstawie art. 63 u.n.m.). Co ciekawe, w praktyce na proces ustalania tych wskaźników przez organ wyznaczony największy wpływ mają wytyczne formułowane w drodze zaleceń Europejskiej Rady ds. Ryzyka Systemowego ${ }^{66}$, co ilustruje charakterystyczny, kilkupoziomowy model regulacji — od form prawa miękkiego (soft law), po akty stricte normatywne.

62 Por. J. Kálmán, Administrative law aspects of the macroprudential regulation and supervision of the financial intermediary system - normativity, organisation, toolkit, „Financial and Economic Review" 15, 2016, nr 3, s. 27-50, http://real.mtak.hu/40451/1/Administrative_law_aspects_of_the_macroprudential_regulation_and_supervisionnof_the_financial_intermediary_system_normativity_organisation_toolkit_u.pdf.

63 Por. S. Wronkowska, Model rozporzadzenia jako aktu wykonawczego do ustaw w świetle konstytucji i praktyki, [w:] Konstytucyjny system..., s. 15-19; K. Działocha, Zamknięty system źródeł prawa powszechnie obowiązującego w konstytucji i praktyce, [w:] Konstytucyjny system..., s. 15-19; A. Adamczyk, op. cit., s. 30-47; K.M. Ziemski, Formy prawne..., [w:] System Prawa Administracyjnego, t. 5, s. 118-122.

64 Wyrok TK z dnia 26 maja 1998 roku, sygn. akt K. 17/98, OTK ZU 1998, nr 4, poz. 48.

65 Od dnia 1 stycznia 2016 roku wskaźnik bufora antycyklicznego wynosi $0 \%$ dla ekspozycji kredytowych na terytorium RP.

66 Przykładowo: zalecenie Europejskiej Rady ds. Ryzyka Systemowego z dnia 18 czerwca 2014 roku w sprawie wytycznych dotyczących ustalania wskaźników bufora antycyklicznego (ERRS/2014/1), (Dz. Urz. UE C 293 z 2.09.2014, s. 1). 
Drugą formą działania stosowaną na podstawie u.n.m. są akty administracyjne indywidualne, czyli decyzje administracyjne ${ }^{67}$. W przedmiotowym obszarze nadzoru ostrożnościowego istnieją przypisane ustawowo kompetencje do wydawania decyzji, jednakże ma je wyłącznie Komisja Nadzoru Finansowego. W świetle ustaleń dotyczących podziału nadzoru ostrożnościowego KNF działa w tych wypadkach jako organ nadzoru mikroostrożnościowego, który po uzyskaniu opinii KSF wydaje decyzje administracyjne w sprawach dotyczących między innymi: określenia globalnych instytucji o znaczeniu systemowym — GSII (w myśl art. 35 ust. 1 u.n.m.) oraz innych niż globalne instytucje o znaczeniu systemowym - OSII (w myśl art. 39 ust. 1 u.n.m.). Obydwa przypadki są przykładem zastosowania administracyjnych aktów kwalifikujących o charakterze zobowiązującym, środków charakterystycznych dla nadzoru bieżącego (weryfikującego) ${ }^{68}$. Konsekwencją tego typu kwalifikacji jest konieczność dostosowania przez wskazane instytucje finansowe ich gospodarki finansowej poprzez wdrożenie dodatkowego wskaźnika bufora kapitałowego. Tego typu mechanizm w założeniu ma dostarczać możliwości koordynacji i pośredniego wpływu KSF na ksztalt tego typu instrumentu mikroostrożnościowego. Co istotne, rola KNF w zakresie całego nadzoru ostrożnościowego obejmuje również kompetencje do wydawania sankcji administracyjnych za naruszenie przepisów u.n.m., które stosowane są w formie indywidualnych decyzji administracyjnych. Mogą one polegać między innymi na: zastosowaniu kar pieniężnych względem osób fizycznych lub instytucji oraz na ograniczeniu zakresu działalności lub cofnięciu zezwolenia na prowadzenie działalności przez instytucję (art. 62 ust. 1 u.n.m.).

\section{KONKLUZJE}

Podstawową determinantą decydującą o zastosowaniu w zakresie nadzoru makroostrożnościowego ukształtowanych w prawie administracyjnym form dzia-

67 Przykładowo pod tym pojęciem określa się, „opartą na ogólnie obowiązujących przepisach prawa, czynność administrującego organu państwa, która jako wyraz jego woli prawnie określa sytuację konkretnie wskazanego adresata w indywidualnie oznaczonej sprawie". Tak J. Starościak, Prawo administracyjne, Warszawa 1969, s. 237. Na podobne elementy wskazują M. Wierzbowski i A. Wiktorowska, którzy do kategorii aktów administracyjnych zaliczają „oparte na przepisach prawa administracyjnego władcze, jednostronne oświadczenie woli organu administracji publicznej, określające sytuację prawną konkretnie wskazanego adresata (strony) w indywidualnie oznaczonej sprawie". Tak M. Wierzbowski, A. Wiktorowska, Prawne formy..., 2017, s. 302.

68 Podstawą do ich wyróżnienia jest charakterystyczny „model wykonywania prawa wyczerpujący się na etapie subsumpcji (kwalifikacji)". Efektem rozstrzygnięcia zawartego w tego typu akcie może być albo kwalifikacja pozytywna, albo klasyfikacja negatywna. Por. K. Kiczka, Wybrane praktyczne problemy administracyjnych aktów kwalifikujących, [w:] Między tradycja a przyszłościa w nance prawa administracyjnego. Ksiega jubileuszowa dedykowana Profesorowi Janowi Bociowi, red. J. Supernat, Wrocław 2009, s. 265-267. 
łania jest potrzeba uzyskania komplementarności działań wszystkich zaangażowanych instytucji (tak zwanych podmiotów właściwych) oraz postulat skuteczności w zapobieganiu sytuacjom niepożądanym (narastaniu ryzyka systemowego). Tego typu spostrzeżenie znajduje swoje odzwierciedlenie w przewidzianych w u.n.m. mechanizmach realizacji celu nadzoru makroostrożnościowego z art. 1 ust. 2 u.n.m. oraz zadaniach przewidzianych dla tego obszaru w art. 5 ust. 1 u.n.m., czyli ,stosowaniu instrumentów makroostrożnościowych, w tym przedstawianiu stanowisk, oraz wydawaniu rekomendacji”. Już samo sformułowanie ustawodawcy expressis verbis sugeruje, że wskazywane formy prawne określane jako „niewładcze” są niewystarczające do urzeczywistnienia w praktyce celów i zadań ustawowych.

W świetle ustaleń prawnoporównawczych główną funkcję w nadzorze makroostrożnościowym pełnią takie formy prawne, jak: rekomendacje, zalecenia czy opinie, zaliczane do coraz popularniejszej, a jednocześnie bardzo szerokiej i niejednolitej kategorii aktów prawa miękkiego (soft law) funkcjonujących $\mathrm{w}$ wielu ponadnarodowych systemach prawnych, między innymi w prawie UE, w którym mają swój rodowód traktatowy. Stosowanie tego typu konstrukcji może oczywiście wywoływać wątpliwości odnośnie do ich skuteczności, w szczególności gdy kompetencje nadzoru makroostrożnościowego ograniczają się wyłącznie do tak zwanych form niewładczych, jednakże na ów problem powinniśmy spojrzeć holistycznie przez pryzmat kompetencji wszystkich instytucji zaangażowanych w proces nadzoru makroostrożnościowego, w tym przede wszystkim KNF, która — jak wynika z powyższego - ma w omawianym zakresie wiele szczególnych kompetencji zabezpieczonych możliwością zastosowania przymusu (sankcji), przewidzianych w u.n.m. i ustawach.

Ogólny proces kształtowania się instrumentarium makroostrożnościowego zarówno w prawie UE, jak i prawie krajowym na podstawie formy soft law pociąga za sobą również określone konsekwencje w warstwie regulacyjnej, gdyż skutkuje brakiem szczegółowych przesłanek zastosowania określonych środków nadzoru, co z kolei otwiera szerokie pole do dyskrecjonalności nadzoru i kalibrowania instrumentów (regulacji). Sprzyja temu sama specyfika posługiwania się przez ustawodawcę w tekście normatywnym wieloma klauzulami generalnymi i zwrotami niedookreślonymi, a w szczególności sposób definiowania kluczowego „ryzyka systemowego" poprzez odwoływanie się do parametrów ekonomicznych, jak: „dynamika akcji kredytowej lub zadłużenia” czy „nierównowaga w zakresie cen aktywów" (art. 4 pkt 15 u.n.m.). Z drugiej strony stosowanie form prawa miękkiego sprzyja kształtowaniu standardów pożądanych przez instytucje sieci bezpieczeństwa finansowego, w tym nadzoru finansowego. W ten sposób pomiędzy nadzorem a instytucjami rynku finansowego kształtuje się kluczowa dla tego obszaru komunikacja pozwalająca na prewencyjne dostosowywanie się adresatów do formułowanych w sposób niewiążący norm określonych na poziomie makro przez KSF, co powinno być jednocześnie wyznacznikiem kierun- 
ku i sposobu widzenia określonych zjawisk przez nadzór mikroostrożnościowy (KNF) w toku indywidualnych postępowań. W tym kontekście de lege ferenda można sformułować postulat rozszerzenia zakresu stosowania rekomendacji KSF ponad ustalone powyżej znaczenie i nadanie jej typowej dla tego nadzoru funkcji niewładczej regulacji (soft law), jak ma to miejsce w przypadku rekomendacji KNF wobec sektora bankowego czy analogicznych form stosowanych w innych państwach. Ponadto tego typu forma w zakresie podmiotowym powinna obejmować również pozostałych „uczestników”, czyli instytucje infrastruktury oraz rynków finansowych, jak ma to miejsce w przytaczanych przykładach porównawczych.

Jak sugerują przyjęte w różnych państwach rozwiązania organizacyjne, differentia specifica nadzoru makroostrożnościowego jest odziaływanie na całość rynku, a nie określonych indywidualnie uczestników, dlatego na poziomie makroostrożnościowym nie ma potrzeb i materialnych podstaw do stosowania środków indywidualnych $\mathrm{w}$ formie władczych aktów administracyjnych. W tym kontekście, jak wynika choćby z zamieszczonego materiału prawnoporównawczego, w krajach, w których powołano organy mające kompetencje wyłącznie w zakresie makroostrożnościowym, nie mają one uprawnień pozwalających na kształtowanie sytuacji prawnej indywidualnych instytucji finansowych, gdyż nie jest to w ogóle ich celem. Taka potrzeba występuje dopiero w obszarze mikroostrożnościowym koncentrującym się na konkretnie wskazanych instytucjach. Tego typu organem jest Komisja Nadzoru Finansowego, która została wyposażona między innymi w kompetencje do nadawania określonych statusów poszczególnym instytucjom finansowym (GSII i OSII), co realizowane jest w drodze decyzji administracyjnych. Ukształtowany w ten sposób system oddziaływania na otoczenie nie wymaga wyposażenia KSF we władcze formy działania, gdyż odziaływanie państwa w sferze „imperium” jest zabezpieczone w inny, pośredni sposób za pomocą współuczestnictwa nadzorcy mikroostrożnościowego (KNF), który jednocześnie sam może być adresatem środków koordynacyjnych (rekomendacji KSF). Należy przy tym pamiętać, że Komisja Nadzoru Finansowego oprócz środków nadzoru mikroostrożnościowego wyposażona jest w spektrum uprawnień kontrolno-nadzorczych (w tym również władczych) skierowanych do instytucji finansowych, a wynikających $\mathrm{z}$ mechanizmów nadzoru czynnościowego określonych w ustawach szczególnych. Tym sposobem można uzyskać pożądany i akcentowany we wstępie efekt koordynacji i zbieżności na gruncie decyzyjnym $\mathrm{w}$ procesie nadzoru ostrożnościowego. W przeciwnym razie wyposażenie organów funkcjonujących na obydwu poziomach (makro i mikro) w dublujące się środki administracyjne o charakterze regulacyjnym i indywidualnym mogłoby dezawuować pokładane cele i prowadzić w najlepszym wypadku do rozmycia odpowiedzialności, a nawet konfliktów interesów i rozbieżności polityki nadzorczej. Ponadto wypatrzałoby to sens i konstrukcję organizacyjną przyjętą dla tego założenia modelowego KSF, który ma być „,organem polityki makroostroż- 
nościowej”, a nie „organem regulacji”, co ze względów podnoszonego braku możliwości wydawania rozporządzeń może być wykonywane jedynie przy użyciu instrumentów perswazyjnych, takich jak stanowiska.

Dlatego pewną klamrą zamykającą rozważania i elementem pozwalającym właściwie ocenić ów problem jest spojrzenie całościowe na proces decyzyjny przez pryzmat celów i zadań w zakresie nadzoru makroostrożnościowego i mikroostrożnościowego, a zatem nie tyle sui generis KSF, ile właśnie zaangażowanych w jego składzie pozostałych organów administracji publicznej, wyposażonych w przewidziane ustawowo indywidualne kompetencje, które powinny być komplementarne względem zadań KSF. W przeciwnym razie ich zastosowanie może również wywoływać zjawiska niepożądane z punktu widzenia stabilności całego systemu. Omawiane rozwiązanie zakłada wypracowanie w miarę spójnej polityki makroostrożnościowej, przekształcanej następnie w konkretne działania właściwych podmiotów, czyli instytucji publicznych odpowiedzialnych za stabilność finansową. Z natury rzeczy analiza skuteczności tego typu mechanizmów i form działania w realizacji celów i zadań ustawowych wykracza poza ramy opracowania o charakterze jurydycznym i może być dokonane jedynie z perspektywy empirycznej, gdy w systemie finansowym wystąpią istotne zagrożenia stabilności finansowej.

\section{BIBLIOGRAFIA}

Adamczyk A., Publicznoprawne formy działania administracji. Teoria i praktyka, Warszawa 2013.

Bałaban A., Akty normatywne wewnętrznie obowiąujące, [w:] Konstytucyjny system źródet prawa w praktyce, red. A. Szmyt, Warszawa 2005.

Błaś A., Formy prawne w sferze działań wewnętrznych administracji publicznej, [w:] System Prawa Administracyjnego, t. 5. Prawne formy działania administracji, red. R. Hauzer, Z. Nie-wiadomski, A. Wróbel, Warszawa 2011.

Bojanowski E., Kaszubowski E., Urzędowe akty wykładni w sferze prawa powszechnego a formy działania administracji publicznej (wybrane formy), [w:] Nowe problemy badawcze $w$ teorii prawa administracyjnego, red. J. Boć, A. Chajbowicz, Wrocław 2009.

Borkowski J., Decyzja administracyjna, Łódź-Zielona Góra 1998.

Capiga M., Gradoń W., Szustak G., Sieć bezpieczeństwa finansowego, Warszawa 2010.

Czech T., Charakter prawny rekomendacji Komisji Nadzoru Finansowego, „Przegląd Prawa Publicznego" 2009, nr 11.

Dobrzańska A., Makroostrożnościowy wymiar regulacji CRDIV/CRR, „Bezpieczny Bank” 2015, nr $1(58)$.

Działocha K., Zamknięty system źródeł prawa powszechnie obowiązującego w konstytucji i praktyce, [w:] Konstytucyjny system źródet prawa w praktyce, red. A. Szmyt, Warszawa 2005.

Ferran E., Alexander K., Can soft law bodies be effective? Soft systemic risk oversight bodies and the special case of the European systemic risk board, „Legal Studies Research Paper Series” 36, 2011.

Garlicki L., Konstytucyjne źródła prawa administracyjnego, [w:] System Prawa Administracyjnego, t. 2. Konstytucyjne podstawy funkcjonowania administracji publicznej, red. R. Hauzer, Z. Niewiadomski, A. Wróbel, Warszawa 2012. 
Iwanicz-Drozdowska M., Sieć bezpieczeństwa finansowego a działalność konglomeratów finansowych, [w:] Konglomeraty finansowe, red. M. Iwanicz-Drozdowska, Warszawa 2007.

Jabłoński M., Krajowe źródła prawa administracyjnego, [w:] Prawo administracyjne, red. M. Wierzbowski, Warszawa 2017.

Jeżewski J., Wewnętrzne prawo administracyjne, [w:] Prawo administracyjne, red. J. Boć, Wrocław 2003.

Jurkowska-Zeidler A., Bezpieczeństwo rynku finansowego w świetle prawa Unii Europejskiej, Warszawa 2008.

Kiczka K., Wybrane praktyczne problemy administracyjnych aktów kwalifikujących, [w:] Między tradycja a przyszłościa w nauce prawa administracyjnego. Księga jubileuszowa dedykowana Profesorowi Janowi Bociowi, red. J. Supernat, Wrocław 2009.

Kohutek K., [w:] Prawo bankowe. Komentarz, t. 2, red. F. Zoll, Kraków 2005.

Krzyżewski J. A., Rekomendacje nadzorcze - charakter prawny i zakres mocy obowiazujacej, „Prawo Bankowe" 2000, nr 7-8.

Mielczarek J., Otwarty katalog aktów prawa wewnętrznego a zasada zaufania do władz publicznych, [w:] Sprawiedliwość i zaufanie do władz publicznych w prawie administracyjnym, red. M. Stahl, M. Kasiński, K. Wlaźlak, Warszawa 2015.

Ochwat M., Nadzór finansowy w Wielkiej Brytanii, „Monitor Prawa Bankowego” 2016, nr 9 (70).

Olszak M., Rekomendacje organu nadzoru bankowego — geneza, przedmiot regulacji, charakter prawny, „Przegląd Ustawodawstwa Gospodarczego” 2010, nr 11.

Osiński J., Stabilność finansowa w Polsce - aspekty systemowe, „Bank i Kredyt” 2005, nr 11-12, dodatek.

Ostalecka A., Sieć bezpieczeństwa finansowego w obliczu rosnącego zagrożenia utraty stabilności systemów finansowych, [w:] Rynek finansowy. Inspiracje z integracji europejskiej, red. P. Karpuś, J. Węcławski, Lublin 2008.

Pawłowicz L., Sieć bezpieczeństwa finansowego w Unii Europejskiej a Strategia Lizbońska, [w:] Strategia Lizbońska a zarządzanie wartościa, red. L. Pawłowicz, Warszawa 2006.

Płowiec W., Koncepcja aktu prawa wewnętrznego w Konstytucji RP, Poznań 2006.

Popik-Chorąży K., Legislacja administracyjna, Warszawa 2013.

Rosati D.K., Regulacje makroostrożnościowe a stabilność sektora bankowego, „Bank i Kredyt” 45, 2014, $\mathrm{nr} 4$.

Smykla B., Prawo bankowe. Komentarz, Warszawa 2011.

Stahl M., Szczególne prawne formy działania administracji, [w:] System Prawa Administracyjnego, t. 5. Prawne formy działania administracji, red. R. Hauzer, Z. Niewiadomski, A. Wróbel, Warszawa 2011.

Starościak J., Prawo administracyjne, Warszawa 1969.

Wierzbowski M., Wiktorowska A., Prawne formy działania administracji, [w:] Prawo administracyjne, red. M. Wierzbowski, Warszawa 2011.

Wierzbowski M., Wiktorowska A., Prawne formy działania administracji, [w:] Prawo administracyjne, red. M. Wierzbowski, Warszawa 2017.

Wronkowska S., Model rozporzadzenia jako aktu wykonawczego do ustaw w świetle konstytucji i praktyki, [w:] Konstytucyjny system źródet prawa w praktyce, red. A. Szmyt, Warszawa 2005.

Zapadka P., Sieć bezpieczeństwa finansowego (safety net) jako element konstytucji gospodarczej Unii Europejskiej, [w:] Konstytucja gospodarcza Unii Europejskiej. Aksjologia, red. A. Nowak-Far, Warszawa 2010.

Ziemski K.M., Formy prawne w sferze działań zewnętrznych administracji publicznej, [w:] System Prawa Administracyjnego, t. 5. Prawne formy działania administracji, red. R. Hauzer, Z. Niewiadomski, A. Wróbel, Warszawa 2011. 
Ziemski K.M., Indywidualny akt administracyjny jako forma prawna działania administracji, Poznań 2005.

Ziemski K.M., Podstawy problematyki, [w:] System Prawa Administracyjnego, t. 5. Prawne formy działania administracji, red. R. Hauzer, Z. Niewiadomski, A. Wróbel, Warszawa 2011.

\section{AKTY PRAWNE}

Dyrektywa Parlamentu Europejskiego i Rady nr 2013/36/UE z dnia 26 czerwca 2013 roku w sprawie warunków dopuszczenia instytucji kredytowych do działalności oraz nadzoru ostrożnościowego nad instytucjami kredytowymi i firmami inwestycyjnymi, zmieniająca dyrektywę 2002/87/WE i uchylająca dyrektywy 2006/48/WE oraz 2006/49/WE (Dz. Urz. UE L 176 z 27.06.2013, s. 338, ze zm.).

Rozporządzenie Parlamentu Europejskiego i Rady (UE) nr 1092/2010 z dnia 24 listopada 2010 roku w sprawie unijnego nadzoru makroostrożnościowego nad systemem finansowym i ustanowienia Europejskiej Rady ds. Ryzyka Systemowego (Dz. Urz. UE L 331 z 15.12.2010, s. 1).

Rozporządzenie Parlamentu Europejskiego i Rady (UE) nr 575/2013 z dnia 26 czerwca 2013 roku w sprawie wymogów ostrożnościowych dla instytucji kredytowych i firm inwestycyjnych, zmieniające rozporządzenie (UE) nr 648/2012 (Dz. Urz. UE L 176 z 27.06.2013, s. 1, ze zm.).

Rozporządzenia Ministra Rozwoju i Finansów z dnia 1 września 2017 roku w sprawie bufora ryzyka systemowego (Dz.U. z 2017 r. poz. 1776).

Ustawa a dnia 14 czerwca 1960 roku Kodeks postępowania administracyjnego (tekst jedn. Dz. Urz. z 2018 r. poz. 2096).

Ustawa z dnia 23 kwietnia 1998 roku o Banku Anglii (Bank of England Act 1998) (1998 c. 11).

Ustawa z dnia 14 grudnia 2000 roku Kodeks pieniężny i finansowy (Code monétaire et financier) aneks do ustawy nr 2000-1223 w kształcie nadanym przez ustawę 2014-158 z 20.02.2014 roku (J.O. nr 29 z dnia 17 grudnia 2000 roku).

Ustawa z dnia 22 kwietnia 2002 roku w sprawie organu nadzoru nad rynkiem usług finansowych (Finanzdienstleistungsaufsichtsgesetz), tekst w wersji zmienionej z 1 stycznia 2014 roku (BGB1. I s. 306).

Ustawa z dnia 28 listopada 2012 roku o stabilności finansowej (Finanzstabilitätsgesetzes) (BGB1. I S. 2369).

Ustawa z dnia 5 lipca 2015 roku o nadzorze makroostrożnościowym nad systemem finansowym i zarządzaniu kryzysowym w systemie finansowym (Dz. Urz. z 2015 r. poz. 1513 ze zm.).

Ustawa z dnia 10 czerwca 2016 roku o Bankowym Funduszu Gwarancyjnym, systemie gwarantowania depozytów oraz przymusowej restrukturyzacji (tekst jedn. Dz. Urz. 2017 poz. 1937).

Zalecenie Europejskiej Rady ds. Ryzyka Systemowego z dnia 22 grudnia 2011 roku w sprawie mandatu makroostrożnościowego organów krajowych (ERRS/2011/3) (Dz. Urz. UE C 41 z 14.02.2012, s. 1).

Zalecenie Europejskiej Rady ds. Ryzyka Systemowego z dnia 18 czerwca 2014 roku w sprawie wytycznych dotyczących ustalania wskaźników bufora antycyklicznego (ERRS/2014/1) (Dz. Urz. UE C 293 z 2.09.2014, s. 1).

\section{ŹRÓDŁA INTERNETOWE}

Ausschuss für Finanzstabilität, Erster Bericht an den Deutschen Bundestag zur Finanzstabilität in Deutschland, AFS, Juni 2014, http://www.bundesfinanzministerium.de/ Content/DE/Downloads/Abt 7/2014-06-18-Bericht-AFS.pdf? blob= publicationFile \&v=4.

BIS: Objective-setting and communication of macroprudential policies, Raport, BIS, CGFS Papers, nr 57, http://www.bis.org/publ/cgfs57.pdf. 
Borio, C. Implementing a macroprudential framework: Blending boldness and realism, BIS, 22 July 2010, http://www.bis.org/repofficepubl/hkimr201007.12c.pdf.

Brzozowski M., CRD IV, CRR - instrumenty makroostrożnościowe, Warszawa 2014, https://www. nbp.pl/systemfinansowy/crdiv-crr.pdf.

ECB: The role of central banks in prudential supervision, 30 March 2001, http://www.ecb.int/ pub/ pdf/other/prudentialsupcbrole_en.pdf.

ESRB: Recommendation on the macro-prudential mandate of national authorities (ESRB/2011/3), Follow-up Report — Overall assessment, June 2014, https://www.esrb.europa.eu/pub/pdf/recommendations/2014/ESRB_2014.en.pdf?600ec3fed1d5300e6a16ef0767b75cc5.

Kálmán J., Administrative law aspects of the macroprudential regulation and supervision of the financial intermediary system - normativity, organisation, toolkit, „Financial and Economic Review" 15, 2016, nr 3, http://real.mtak.hu/40451/1/Administrative_law_aspects_of the_macroprudential_regulation_and_supervisionnof_the_financial_intermediary_system_normativity_organisation_toolkit_u.pdf.

Stratégie du Haut Conseil de stabilité financière, HCSF, https://www.economie.gouv.fr/files/strategie_macroprudentielle_du_hcsf.pdf.

\section{LEGAL FORMS OF ACTIVITIES OF THE FINANCIAL STABILITY COMMITTEE}

\section{Summary}

The basic aim of this study is to present the nature of the legal forms of administration activities granted by the legislator, applied by the Financial Stability Committee [Komitet Stabilności Finansowej] in the light of administrative law. The specificity of conduct of macroprudential policy and supervision in Poland as well as in compared legal systems is primarily based on the use of forms of non-imperative nature, and that is why it is reasonable to examine what the effectiveness of this mechanism of impact on financial market institutions is and whether in this context it is possible to implement the goal of financial stability.

Keywords: financial market, supervision, macroprudential policy, legal forms of activities 